\title{
Influence of abiotic factors on populations of Carollia perspicillata (Linnaeus 1758) (Mammalia, Chiroptera)
}

\author{
Influencia de factores abióticos en poblaciones de Carollia \\ perspicillata (Linnaeus 1758) (Mammalia, Chiroptera)
}

D.0.I.: https://doi.org/10.30550/j.azl/2018.62.2/3

\author{
Adrián Alonso Durán ${ }^{1,2}$ * \\ 1 Grupo de Investigación en Zoología y Ecología, Universidad de Sucre. Cra 28 \# 5 267, Barrio Puerta \\ Roja, Sincelejo, Sucre, Colombia. \\ 2 Centro de Estudos de Biodiversidade, Universidad Federal de Mato Grosso do Sul (UFMS). Avenida \\ Costa e Silva, s/n, Universitário, CEP 79070 900, Campo Grande, MS, Brasil \\ * Correspondencia: adurandelaossa@gmail.com
}

\begin{abstract}
- Abstract - The Amazon is a region of South America considered of vital importance due to its high biodiversity. It is considered as one of the most productive terrestrial ecosystems on the planet, due to its structural and landscape complexity. It harbors a great diversity of bats, being Carollia perspicillata (Phyllostomidae) one of the most commonly recorded, it is mainly frugivorous, foraging in the lowest stratum of the forest, there are few studies about its ecology and even less in the Amazon region; therefore, this study aims to evaluate the influence of abiotic factors (temperature, seasonality, illuminated phase of the Moon) on a population of the aforementioned species in the Brazilian Amazon. For the capture of bats, 8 mist nets were used in terra firme forest in the Brazilian central Amazon. The temperature data were provided by the National Institute of Meteorology (INMET-Brazil), while the percentage of illuminated phase of the Moon for each day of collection was obtained by Moontool version 2.0 Software. In total, 888 individuals were captured: 358 males and 530 females. A higher frequency of young individuals (for both sexes) was recorded in the rainy season, as well as lactating females and the total of individuals recorded. The weight of the bats does not seem to respond to the climate season. The temperature did not significantly influence the abundance of individuals, however the percentage of illuminated phase of the Moon does, as has already been demonstrated by other authors, responding to a phenomenon known as «moon phobia». Results suggest that abiotic factors may influence on populations of this bat species in the forests of the Brazilian Amazon.
\end{abstract}

Keywords: Amazon, Carollia, abiotic factor, Phyllostomidae.

> Resumen - El Amazonas es una región de Sudamérica, considerada de vital importancia por su alta biodiversidad. Se constituye como uno de los ecosistemas terrestres más productivos del planeta, debido a su complejidad estructural y paisajística, alberga una gran riqueza de murciélagos, siendo Carollia perspicillata (Phyllostomidae) una de las más comúnmente registradas, es principalmente frugivora, forrajeando en el estrato más bajo del bosque, son pocos los estudios acerca de su ecología y menos aún en la región amazónica; por consiguiente, el presente estudio pretende evaluar la influencia de factores abióticos en una población de la

\footnotetext{
$>$ Ref. bibliográfica: Durán, A. A. 2018. Influence of abiotic factors on populations of Carollia perspicillata (Linnaeus 1758) (Mammalia, Chiroptera). Acta zoológica lilloana 62 (2): 24-30.

> Recibido: 21/06/18 - Aceptado: 28/09/18

> URL de la revista: http://actazoologica.lillo.org.ar

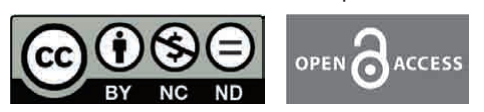

$>$ Algunos derechos reservados. Esta obra está bajo una Licencia Creative Commons Atribución - No Comercial - Sin Obra Derivada 4.0 Internacional.
} 
mencionada especie en el Amazonas brasilero. Para la captura de murciélagos se emplearon 8 redes de niebla en el bosque de terra firme en la amazonía central brasilera. Los datos de temperatura fueron proporcionados por el Instituto Nacional de Meteorología (INMET-Brasil), mientras que el porcentaje de fase iluminada de la Luna para cada día de colecta se obtuvo mediante el software Moontool v. 2.0. En total fueron capturados 888 individuos: 358 machos y 530 hembras. Fue registrada una mayor frecuencia de individuos jóvenes (para ambos sexos) en la temporada de lluvias, así como de hembras lactantes y total de individuos registrados. El peso de los murciélagos no parece responder a la temporada climática. La temperatura no influenció significativamente las abundancias de individuos, sin embargo, el porcentaje de fase iluminada de la Luna sí, respondiendo a un fenómeno conocido como «fobia lunar». Los resultados sugieren que el clima sí puede influenciar en las poblaciones de esta especie de murciélago en los bosques de la Amazonía brasilera.

Palabras clave: Amazonas, Carollia, factores abióticos, Phyllostomidae.

The Amazon region is a highly productive type of ecosystem, mainly due to its structural and landscape complexity (Holdridge, 1967; Myster, 2009). Its biodiversity is, in many aspects, unique (Daly and Prance, 1989), which is why it is considered one of the most important tropical forests in the world (Keller et al., 2004).

\section{Carollia perspicillata (Linnaeus 1758)} (Figure 1) is a bat belonging to the Phyllostomidae family, found in deciduous forests from Mexico to southern Brazil, being very common in secondary forests (Cloutier and Thomas, 1992, Durán and Canchila, 2015). This species is typically frugivorous (Muñoz, 2001; Gardner, 2008) and highly recorded in

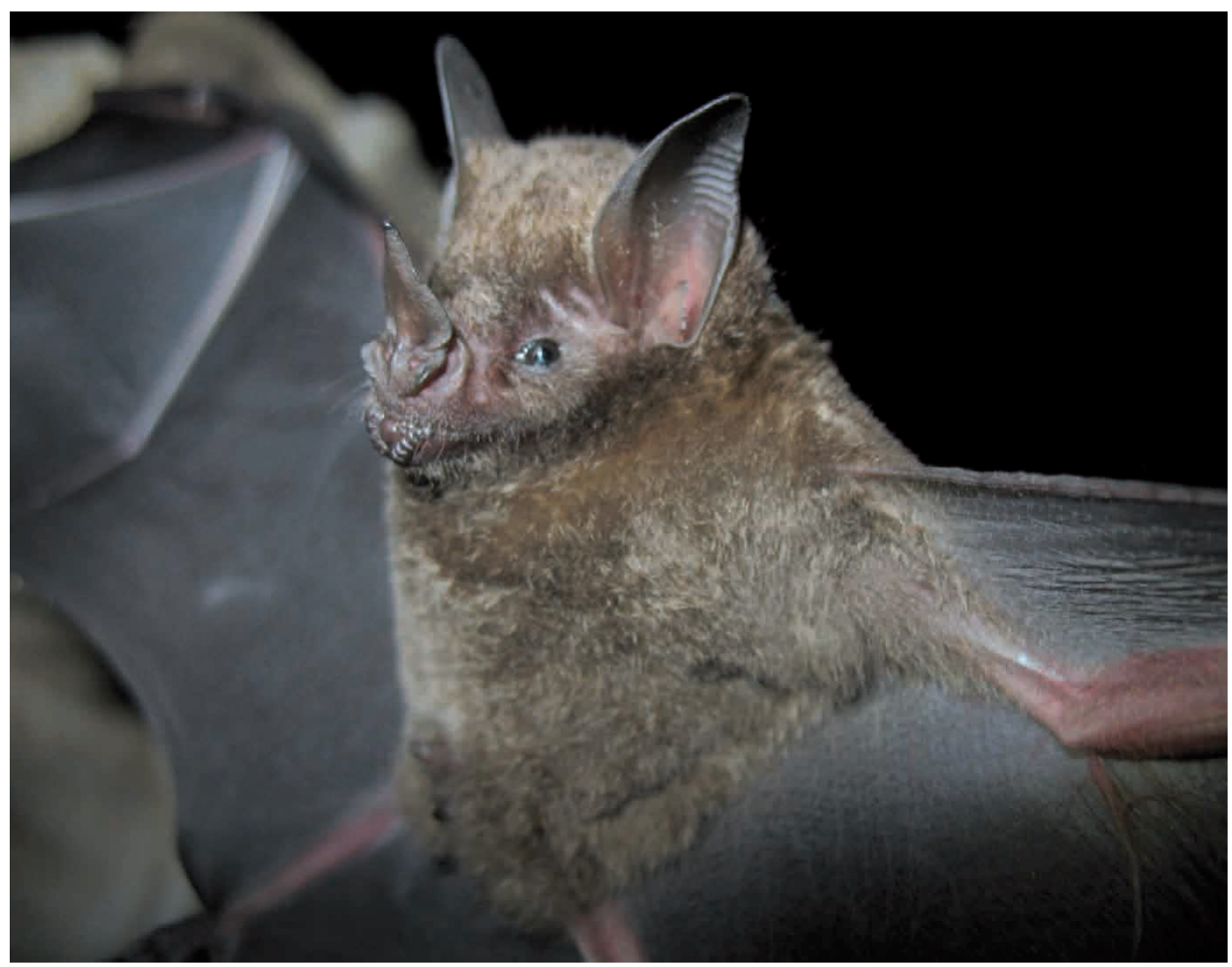

Figure 1. Carollia perspicillata (Phyllostomidae). Source: A. F. Eriksson. 
understory mainly due to its foraging habits (Bonaccorso, 1979; Stoner, 2005).

Studies conducted in Panama and Costa Rica have found that these bats are seasonal in terms of their reproductive patterns: from June-August (during the rainy season) and between the months of February-May (during the dry season) (Cloutier and Thomas, 1992). Likewise, other studies, such as Mello et al. (2009), have found that in the bat Sturnira lilium the temperature turned out to be a very important factor in the ecology of the species; while, Esbérard (2007) found that the percentage of illuminated phase of the moon determines the representativeness of bat species in an assembly, due to its detection and catchability.

There is little research on the ecology of the species in question, and even less in the Amazon region; therefore, the objective of this study is to evaluate whether abiotic factors (temperature, seasonality, illuminated phase of the Moon) influence on populations of $C$. perspicillata in the forests of the Brazil- ian Amazon. The proposed hypothesis is that the seasonality to have a strong influence on the population structure of the species, as well as the temperature and the illuminated phase of the Moon since they are very important factors in the catchability of the bats, as has been demonstrated in other species of the same subfamily (for example, Esbérard, 2007; Mello et al., 2009; Saldaña-Vázquez and Munguía-Rosas, 2012)

The study area includes the municipalities of Porto Velho and Jaci Paraná in the state of Rondónia (northern Brazil), located on the margin of the Madeira river in the Amazon region (Figure 2). This river is one of the largest tributaries of the Amazon River accounting for around $15 \%$ of its volume (Goulding et al., 2003).

The region presents an average annual rainfall of 1700 to $2000 \mathrm{~mm}$, with a period of rain between the months of November to April and a period of low precipitation from June to September. The vegetation is typical of the dense tropical forest, with mosaics

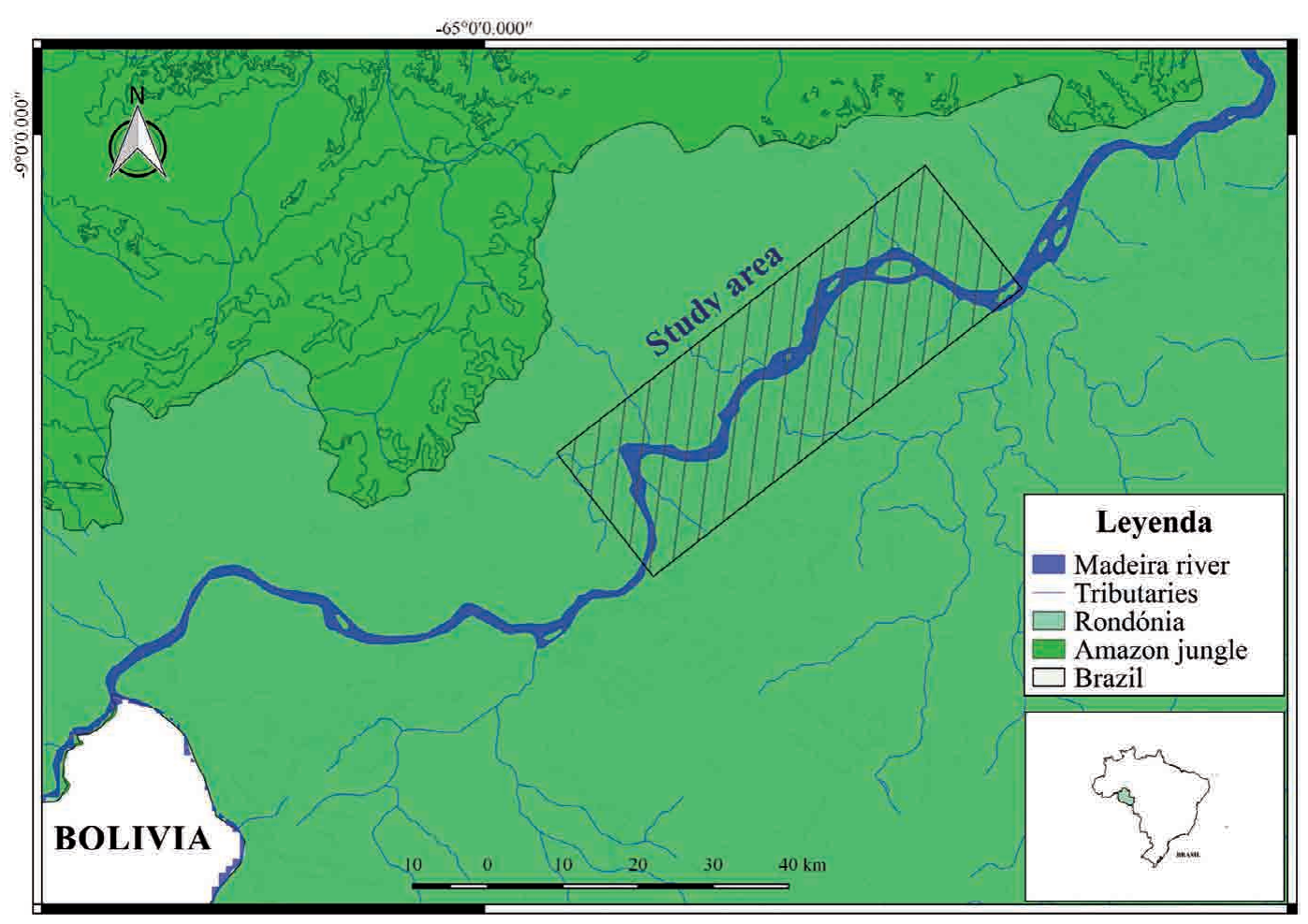

Figure 2. Location of the study area in the Brazilian Amazon region. 
of terra firme forests and seasonally flooded forests, without anthropic intervention (Veloso et al., 1991).

The study was carried out during the months of April, May, June, July September, November, December 2010 and April, May, June, August and September 2011 covering 62 nights of sampling and considering the climatic season (rainy and dry).

For the capture of bats of the species $C$. perspicillata were used eight mist nets of 12 x 2.4 meters open at understory level from 18:00 - 00:00 h, checked every 30 minutes. The captured individuals were transported in cloth bags to the camp, where they were marked with a unique tattoo number, measured, weighed, sexed and later released.

The characteristics for the description of the species follow Muñoz (2001): they are robust, of medium size (mass $=18.5 \mathrm{gr}$ and total length $=66-95 \mathrm{~mm}$ ), the nose leaf is short and triangular. The lower lip is «V》 shaped and has a mentonian foramen surrounded by smaller ones. The fur is dense and the coloration goes from dark brown to lighter (Figure 1).

The sampling effort was calculated by multiplying the length by the width of the mist nets, by the number of open hours, by the number of nights and number of nets used. The result was expressed in $\mathrm{m}^{2}$ mist / hour based on the method proposed by Medellín (1993) and modified by López et al. (2009). The Chi-square test determined the existence of statistically significant differences between age (juvenile, adult) and reproductive condition (females: lactating and pregnant, males: scrotal and non-palpable testes), with respect to the climatic season (rainy, dry) (Legendre and Legendre, 2012). Likewise, it was evaluated if the weight of the bats was influenced by the same variable, using a t-test; later a density graph was made with the «qplot» function of the ggplot2 package for the R v. 3.12 platform.

The temperature data were taken from the Porto Velho-A925 station of the National Institute of Meteorology (INMET-Brazil), however, there were only available data for June, July, September, November and December 2010 and April and May 2011. While, the data of the percentage of illuminated phase of the moon were obtained by means of the software Moontool for Windows 2.0 (Walker, 1999). Subsequently, Pearson correlations were performed to determine significant relationships between the abundances of bats and the previously exposed variables.

A total of 888 individuals were capturing
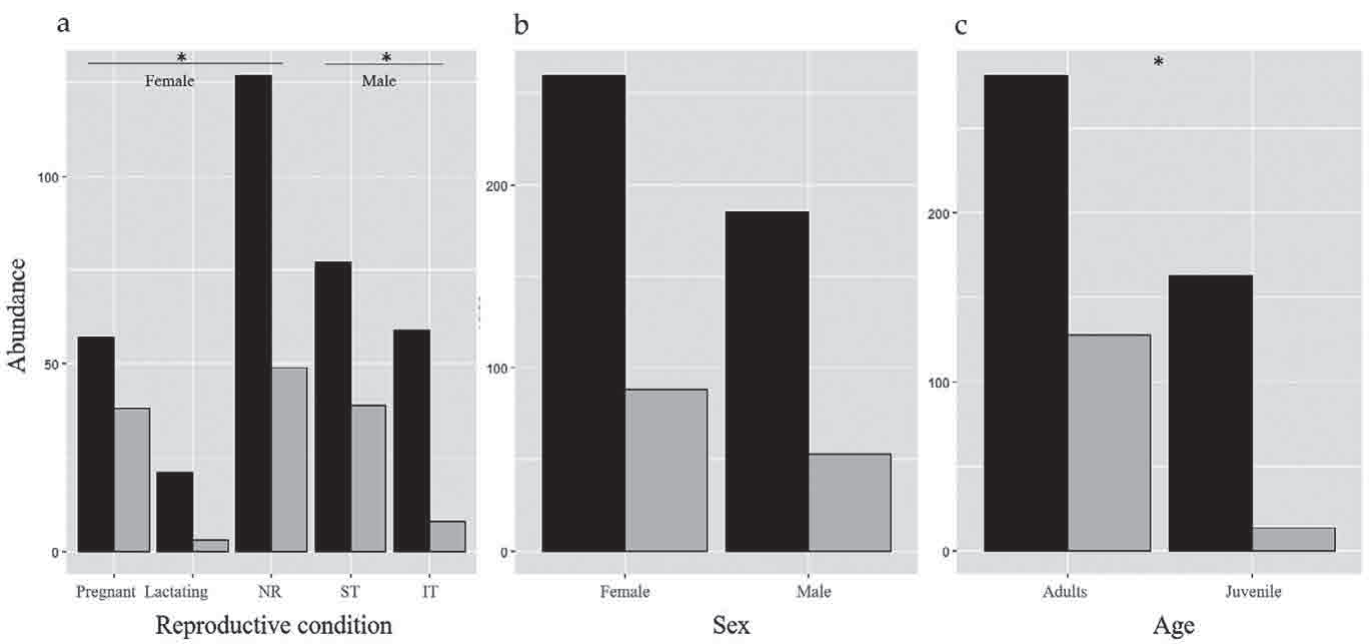

Figure 3. Number of individuals according to: a) reproductive condition. NR = Non Reproductive, ST = Scrotal Testes, IT = Impalpable Testes b] Sex, and c] Age, for each climate season. Black Bars = rainy, Gray Bars = dry. * = Significant differences $P<0.01$. 


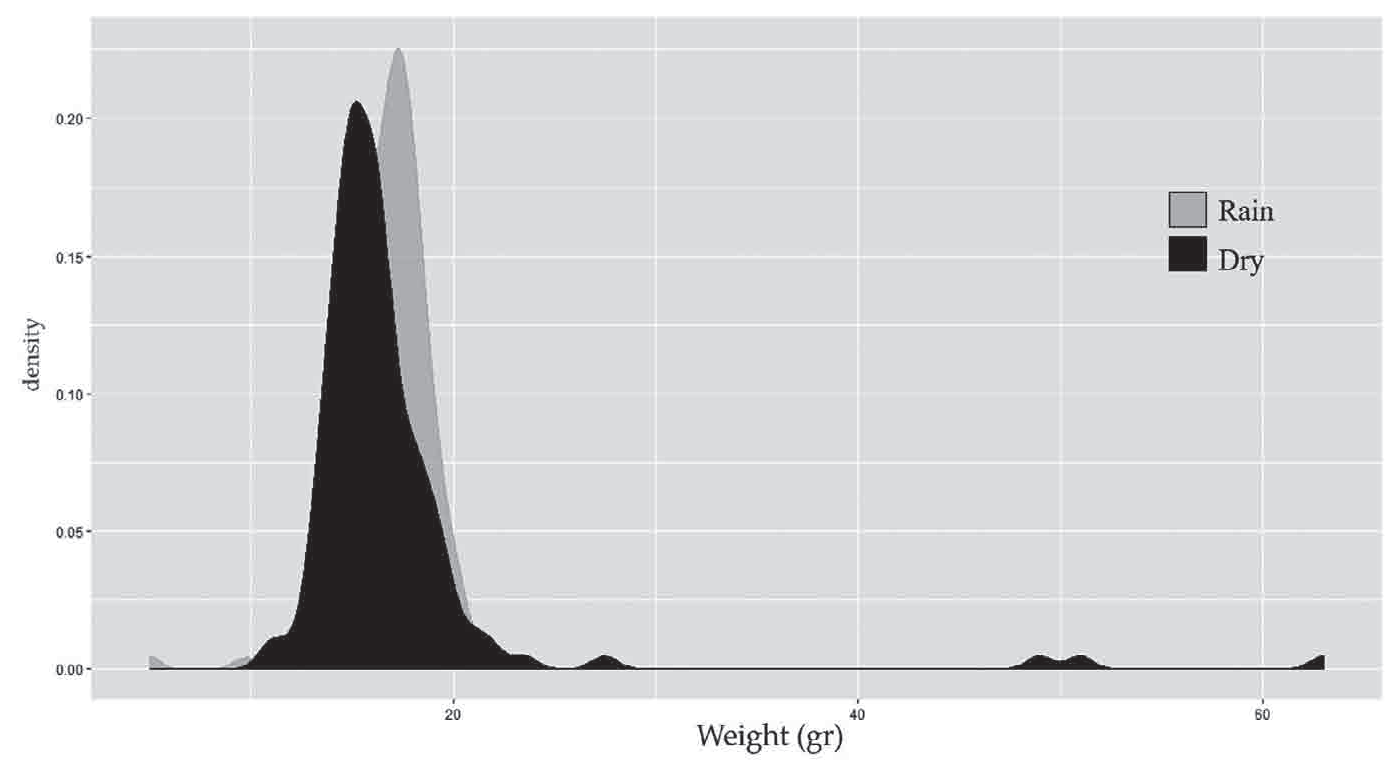

Figure 4. Weight of the recorded individuals according to the climate season.

with a sampling effort of $85708.8 \mathrm{~m}^{2}$. net / hour: 358 males and 530 females, of which 21 were recaptured (not included in the analyzes). Considering the climate season (rainy and dry), there were significant differences between the reproductive condition (female: $X^{2}=18.770$, df $=2, P=0.000$, male: $X^{2}=9.353$, df $=1, P=0.002$ ) and age $\left(X^{2}=36.987\right.$, df $\left.=1, P=0.000\right)$, but not for sex $\left(X^{2}=0.549\right.$, df $\left.=1, P=0.458\right)$ (Figure 3).

On the other hand, considering the weight of the individuals (and even if extreme data are recorded), no differences can be seen with respect to the climatic period $(t=1.473, \mathrm{gl}=$ 882.81, $P=0.141$ ) (Figure 4).

The temperature did not seem to significantly influence the catches $(t=-0.908$, df $=26, P=0.371$ ), however the illuminated phase of the Moon showed great influence $(t$ $=-2.692$, $\mathrm{df}=26, P=0.012$ ) (Figure 5).

The results suggest that abiotic factors have an important influence on the populations of $C$. perspicillata in the Brazilian Amazon, with which the proposed hypothesis is fulfilled. a

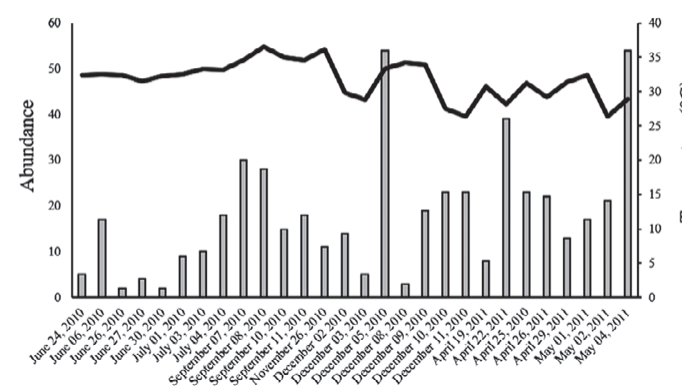

b

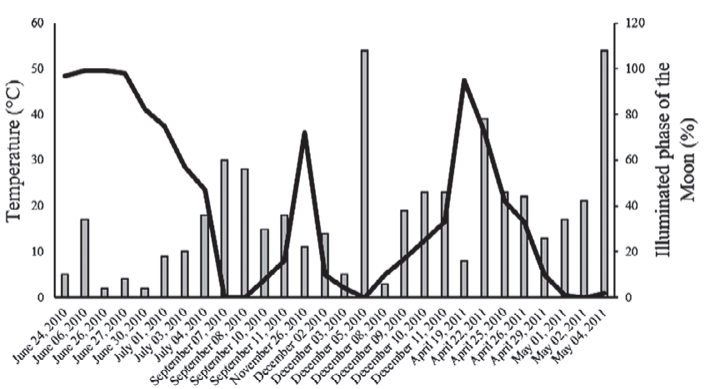

Figure 5. Monthly variation of the abundances of $C$. perspicillata, with respect to a) the temperature $\left({ }^{\circ} \mathrm{C}\right.$ ) (black line) and, b] Percentage of the illuminated phase of the Moon (black line). 
A greater proportion of individuals (of both sexes) was recorded in the rainy season (Table 1), possibly responding to a greater availability of resources (Lim and Engstron, 2001; Stoner, 2005; Pereira et al., 2010). However, the weight does not seem to have responded to this variable, with which, Pereira et al. (2010) suggest that a seasonal variation in fruit availability does not necessarily imply that this resource is limiting for frugivorous bats during part of the year. This can be abundant throughout the year, and during the fruiting peak there may be a surplus of food that is not consumed.

Moreover, the greater abundance of lactating females during the rainy season is consistent with what was recorded in Cloutier and Thomas (1992), indicating that the reproductive periods in the forests of Panama and Costa Rica may be similar to those of the Amazon. Likewise, Mello et al. (2004), in the Atlantic forest in Brazil, found that fruit production and temperature are very important variables in the reproduction of the species.

The percentage of illuminated phase of the Moon had a great influence on the captures, as has already been found by other authors (Esbérard, 2007, Saldaña-Vázquez and Munguía-Rosas, 2012), responding to a phenomenon known as «moon phobia», whereas, due to the fact that the temperature did not show such a marked variation (on the days of capture of the study, see Figure 5) and no data were available of temperature for all sampling days it cannot be concluded that there is no correlation between this variable and the catches. In a study conducted by Mello et al. (2009) in the Sturnira lilium species, found that the temperature has a strong influence on the catches and reproductive cycles of the species, in the Atlantic forest in Brazil. It is necessary to carry out a more prolonged study (month to month) for $C$. perspicillata, relating the catches with temperature data so that a more solid conclusion is reached, refuting or confirming the data found in this studio.

\section{ACKNOWLEDGMENTS}

I am grateful to the National Institute of Amazonian Research (INPA), Manaus (Brazil) for the data provided for the study, as well as to the National Council for Scientific and Technological Development (CNPq) for the granting of the scholarship for the completion of the master's degree, and to the Federal University of Mato Grosso do Sul, Campo Grande (Brazil). Furthermore, 1 would like to thank A. F. Eriksson for the photos of the specimen.

\section{FUNDING}

The work was conceived thanks to the data provided by the National Institute of Amazonian Research (INPA) and the grant given by the National Council for Scientific and Technological Development (CNPq) process: 131544 / 2016-0.

\section{PARTICIPATION}

The only author of the paper, Adrián Alonso Durán, made the entire study.

\section{CONFLICTS OF INTEREST}

The author guarantees that there is no conflict of interest of any kind

\section{LITERATURE CITED}

Bonnacorso F.J. (1979). Foraging and reproductive ecology in a panamanian bat community. Bulletin Florida State Museum of Biological Science, 24, 359408.

Cloutier D., Thomas D. W. (1992). Carollia perspicillata. Mammalian Species, 417. $1-9$.

Daly D. G., Prance G. T. (1989). Brazillian Amazon. In. Floristic inventory of tropical countries (217-220). New York Botanical Garden, Bronx.

Durán A. A., Pérez S. C. (2015). Ensamblaje de murciélagos (Mammalia, Chiroptera) en dos zonas del departamento de Sucre, Colombia. Acta Zoológica Mexicana (n.s), 31, 358-366.

Esbérard C. E. L. (2007). Influência do ciclo lunar na captura de morcegos Phyllostomidae. Iheringia, Séries Zoológicas, 97, 81-85. 
Holdridge L. R. (1967). Life zone Ecology. Tropical Science Center, San José Costa Rica.

Gardner A. L. (2008). Mammals of South America vol. 1. Marsupials, Xenarthrans, Shrews and Bats. The University Chicago Press, Chicago and London.

Goulding M., Barthem R., Ferreira E. (2003). The Smithsonian atlas of the Amazon. Smithsonian Institution Press, Washington, D.C.

Keller M., Alencar A., Asner G. P., Braswell B., Bustamante M., Davidson E., Feldpausch T., Fernandes E., Goulden M., Kabat P., Kruijt B., Luizao F., Miller S., Markewitz D., Nobre A. D, Nobre C. A., Filho N. P., Da Rocha H., Dias P. S., Von Randow C., Vourlitiis G. L. (2004). Ecological research in the large-scale biosphere atmosphere experiment in Amazonia: early results. Ecological Applicatons, 14, S3-S16.

Legendre P., Legendre L. (2012). Numerical Ecology. Elsevier, Oxford, UK.

Lim B. K., Engstrom M. D. (2001). Species diversity of bats (Mammalia: Chiroptera) in Iwokrama Forest, Guyana, and the Guianan subregion: implications for conservation. Biodiversity Conservation, 10, 613-657.

López J. A., Lorenzo C., Barragán F., Bolaños J. (2009). Mamíferos terrestres de la zona lagunar del istmo de Tehuantepec, Oaxaca. Revista Mexicana de Mastozoología, 9, 6-20.

Medellín R. A. (1993). Estructura y diversidad de una comunidad de murciélagos en el trópico húmedo mexicano. En Avances en el estudio de los mamíferos de México (333-354). Ciudad de México: Asociación Mexicana de Mastozoología.
Mello M. A. R., Kalko E. K. V., Silva W. R. (2009). Ambient temperature is more important than food availability in explaining reproductive timing of the bat Sturnira lilium (Mammalian: Chiroptera) in a montane atlantic forest. Canadian Journal of Zoology, 87, 239-245.

Mello, M. A. R., Schittini G. M., Selig P., Bergallo H. G. (2004). A test of the effects of climate and fruiting of Piper species (Piperaceae) on reproductive patterns of the bat Carollia perspicillata (Phyllostomidae). Acta Chiropterologica, 6, 309-318.

Myster R. W. (2009). Plant communities of western Amazonia. Botanical Review, 75, 271-291.

Muñoz J. (2001). Los murciélagos de Colombia. Sistemática, distribución, descripción, historia natural y ecología. Editorial Universidad de Antioquia, Medellín.

Pereira M. J., Marques J. T., Palmeirin J. M. (2010). Ecological responses of frugivorous bats to seasonal fluctuations in fruit availability in Amazonian forest. Biotropica, 42, 680-687.

Saldaña-Vásquez R. A., Munguía-Rosas M. A. (2013). Lunar phobia in bats and its ecological correlates: A meta-analysis. Mammalian Biology, 78, 216-219.

Stoner K. (2005). Phyllostomid Bat Community Structure and Abundance in Two Contrasting Tropical Dry Forests. Biotropica, 37, 591-599.

Veloso H. P., Rangel A. L. R., Lima J. C. (1991). Classificação da vegetação brasileira, adaptada a um sistema universal. IBGE, Rio de Janeiro, Brasil.

Walker J. (1999). Moontool for Windows. http://www. fourmilab.ch/moontoolw/. Accesado: 12 febrero de 2018. 